\title{
INFRASTRUKTURA SPOŁECZNA A ZASPOKOJENIE POTRZEB MIESZKAŃCÓW GMINY STRYKÓW
}

Dr hab. Agnieszka Rochmińska, prof. nadzw. UŁ - Uniwersytet Łódzki

Adres korespondencyjny:

Wydział Nauk Geograficznych Instytut Zagospodarowania Środowiska i Polityki Przestrzennej

ul. Kopcińskiego 31, 90-142 Łódź

e-mail: agnieszka.rochminska@geo.uni.lodz.pl

Mgr Kalina Pędziwiatr (doktorantka) - Uniwersytet Łódzki

Adres korespondencyjny:

Wydział Nauk Geograficznych

Instytut Zagospodarowania Środowiska i Polityki Przestrzennej

ul. Kopcińskiego 31, 90-142 Łódź

e-mail: kalinapedziwiatr@gmail.com

ZARYS TREŚCI: Gmina Stryków to jedna z najszybciej rozwijających się gospodarczo gmin w Polsce. Jednakże, wraz z rozwojem gospodarczym nie jest współmierny rozwój infrastruktury społecznej, która odgrywa ważną rolę w funkcjonowaniu społeczności lokalnych i ma istotny wpływ na zaspokajanie potrzeb mieszkańców. W związku z powyższym, w lipcu 2017 roku na terenie gminy Stryków przeprowadzone zostały badania sondażowe, które pozwoliły badaczom pozyskać informacje na temat wiedzy mieszkańców o inwestycjach samorządowych zrealizowanych w ostatnich pięciu latach. W trakcie badań respondenci mieli również możliwość wskazania swoich potrzeb w zakresie infrastruktury oraz dostępności do usług. Na podstawie odpowiedzi ankietowanych zauważyć można, że w przestrzeni widzą oni głównie inwestycje związane z infrastrukturą techniczną, a nie społeczną. Natomiast brakuje im w niej głównie kompleksów sportowo-rekreacyjnych, które są elementem infrastruktury społecznej. Wyniki przeprowadzonych badań pozwolą na lepszą identyfikację potrzeb mieszkańców, a w późniejszym czasie również na trafniejsze ich zaspokajanie przez władze lokalne.

SŁOWA KLUCZOWE: infrastruktura społeczna, usługi, potrzeby mieszkańców, Stryków. 


\title{
SOCIAL INFRASTRUCTURE AND NEEDS FULLFILMENT OF STRYKÓW COMMUNE RESIDENTS
}

\begin{abstract}
Commune of Stryków is one of the fastest growing economic communities in Poland. However, economic development is not commensurate with the development of social infrastructure, which plays an important role in the functioning of local communities and has a significant impact on meeting the needs of residents. In connection with the above, in July 2017, in the Stryków commune was conducted a survey, which allowed researchers to obtain information on inhabitants knowledge about local government investments realized in the last five years. During the research, respondents also had the opportunity to indicate their needs in terms of social infrastructure and access to services. On the basis of respondents answers, it can be noticed that they see mainly investments related to technical, not social, infrastructure in space. While, they mainly show lack of sports and recreations complexes, which are part of social infrastructure. The research results will allow for better identification of residents needs, and later also for better fultimenting these needs by the local government.
\end{abstract}

KEYWORDS: social infrastructure, services, needs of residents, Stryków.

\subsection{Wprowadzenie}

Infrastruktura społeczna odgrywa bardzo ważną rolę w funkcjonowaniu społeczności lokalnych. Niedocenianie jej przez władze lokalne uwidacznia się w niezadowoleniu mieszkańców, wynikającym z pogarszania jakości ich życia oraz w negatywnym postrzeganiu miejsca zamieszkania i samych władz lokalnych. Słabe wyposażenie wielu terenów w obiekty infrastruktury społecznej (brak obiektów, słaby stan techniczny, mało atrakcyjna oferta) przyczynia się do negatywnej oceny terenów przez osoby je zamieszkujące. Trudno sobie wyobrazić życie mieszkańców bez istnienia i należytego funkcjonowania obiektów infrastruktury społecznej.

Ważna jest szczególnie dostępność urządzeń i instytucji infrastrukturalnych, na co składa się m.in. „ich odpowiednie rozmieszczenie, możliwość dojścia czy dojazdu, odpowiednia pojemność w sensie dostępności dla każdego w danej chwili i poziom świadczonych usług" (Kapusta 2012: 322). Dostępność tych zasobów, często w sposób bezpośredni, przekłada się na atrakcyjność miejsca zamieszkania i wpływa na subiektywnie postrzeganą jakość życia (Błaszczyk, Kłopot, Pluta 2010: 109).

Badania sondażowe w gminie Stryków zostały zrealizowane w lipcu 2017 roku przez studentów kierunku Gospodarka przestrzenna Wydziału Nauk Geograficznych Uniwersytetu Łódzkiego, we współpracy z Urzędem Miasta i Gminy Stryków. Objęły one 494 osoby, co stanowiło 4\% populacji badanego obszaru. Liczbę wywiadów przeprowadzonych w każdym z sołectw starano się powiązać ze strukturą rozmieszczenia ludności. W samym mieście przeprowadzono blisko 1/4 ogółu wywiadów, pozostałe w poszczególnych sołectwach gminy. 
W artykule skoncentrowano się na inwestycjach i potrzebach infrastrukturalnych w gminie Stryków, która w ostatnich latach bardzo szybko rozwinęła się gospodarczo, za czym nie podążył rozwój infrastruktury społecznej (na potrzeby tej pracy traktowano ją jako bazę materialną usług). Głównym zadaniem postawionym przed badaczami było pozyskanie informacji na temat wiedzy mieszkańców o zrealizowanych inwestycjach samorządowych w ostatnich pięciu latach oraz identyfikacja zapotrzebowania na dalsze działania inwestycyjne, ze szczególnym naciskiem na inwestycje z zakresu infrastruktury społecznej. Bardzo ważnym celem badań była również ocena dostępności usług oraz identyfikacja braków w tej dziedzinie.

\subsection{Infrastruktura spoleczna - zakres pojęciowy}

Nie ma jednolitej, bezspornej definicji infrastruktury społecznej. Autorzy zajmujący się infrastrukturą dopasowują definicje do celów własnych opracowań. W wąskim znaczeniu sensu stricte infrastruktura stanowi bazę materialną usług (np. Naumowicz 1992) i jest utożsamiana z ,zespołem/kompleksem urządzeń użyteczności publicznej" (Podoski 1978; Palonka 1992; Kupiec i in. 2004), której „synonimem są obiekty świadczące usługi” (Sadowy 1988; Kozłowski 2012). Inni rozszerzają zakres pojęciowy o instytucje świadczące usługi, np. „infrastruktura społeczna to obiekty materialne plus instytucje” (Budner 2003), „urządzenia i instytucje świadczące usługi” (Kroszel 1990), „,w skład infrastruktury społecznej wchodzą obiekty i urządzenia” (Rutkowska 2007), „sieć urządzeń i instytucji” (Rogoziński 1993), „system składający się z obiektów i instytucji” (Chmielewski 2001), „całokształt cywilizacyjnych urządzeń i instytucji” (Mirowski 1996).

W najszerszym ujęciu sensu largo infrastruktura to urządzenia i pozostałe czynniki świadczenia usług (funkcjonowanie instytucji) oraz usługi i ich efekty (Brol 1995). W takim rozumieniu ,nie jest ona ograniczona tylko do samych urządzeń, ale składa się także z instytucji i pracowników świadczących i wykonujących te usługi oraz rozwiązań organizacyjnych i obowiązujących uregulowań prawnych" (Mikołajewicz 1992: 10-11; Dolata, Łuczka-Bakuła 2005: 10; Witkowski, Starościc 2008: 180). R. Brol (1995: 56) wskazuje, że infrastruktura społeczna świadczy swe usługi najczęściej, a czasami jedynie, przez zespoły ludzkie, tzw. instytucje i samo wyposażenie określonego terenu $\mathrm{w}$ bazę materialną (budynki szkolne, szpitalne, obiekty kultury itd.) nie jest tożsame z zaspokajaniem potrzeb społecznych zgłaszanych przez ludność.

Do infrastruktury społecznej zalicza się najczęściej urządzenia i instytucje świadczące usługi w zakresie oświaty i wychowania, upowszechniania kultury i sztuki, ochrony zdrowia, opieki społecznej, kultury fizycznej, sportu, turystyki, wypoczynku i rekreacji (m.in. Sadowy 1988; Kroszel 1990; Mikołajewicz 1991; Dolata, Łuczka-Bakuła 2005; Borsa 2007; Rutkowska 2007; Kapusta 2012; 
Kozłowski 2012; Kołodziejczyk 2014). G. Rutkowska (2007) kwalifikuje też do nich organizacje społeczne i obiekty kultu religijnego. Zespół instytucji i usług zaspokajających w zorganizowany sposób ludzkie potrzeby również w dziedzinie budownictwa mieszkaniowego jest w niektórych przypadkach zaliczany do omawianej kategorii infrastruktury (Wielka encyklopedia 2002). W obrębie infrastruktury społecznej, obok wyżej wymienionych urządzeń, obiektów i instytucji, W. Budner (2003: 124) wymienia jeszcze te związane $\mathrm{z}$ handlem, usługami rzemieślniczymi, gastronomią, administracją rządową i samorządową, strażą pożarną, instytucje prawa, porządku publicznego i inne.

Infrastruktura społeczna występuje w polityce społecznej w dwóch układach: instytucjonalnym, jako podbudowa materialna zaspokajania potrzeb o szczególnym znaczeniu dla kraju i społeczeństwa oraz funkcjonalnym, jako środek materialny realizacji zadań z określonych dziedzin polityki społecznej i planowania społecznego (Rajchel 2004: 254). Do układu społecznego L. Kupiec i in. (2004: 18) zaliczają: edukację, ochronę zdrowia i opiekę socjalną, kulturę i sztukę, turystykę i wypoczynek, sport i kulturę fizyczną, handel detaliczny i hurtowy, hotelarstwo i gastronomię oraz inne urządzenia i działania gospodarki komunalnej nieujęte w infrastrukturze ekonomicznej. Natomiast do układu instytucjonalnego: administrację publiczną i samorządową, wymiar sprawiedliwości (np. sądy, prokuratury), bezpieczeństwo publiczne i obronę narodową, finanse i ubezpieczenia, organizacje polityczne, społeczne, zawodowe, związków zawodowych, wyznaniowe i międzynarodowe (Kupiec 2004: 17). Z takim stanowiskiem nie zgadza się R. Brol (1995: 56), który zawęża katalog urządzeń i instytucji do tych, które służą mieszkańcom jako całości lub anonimowym grupom społeczeństwa, tym samym wyklucza z infrastruktury społecznej administrację publiczną, sądownictwo, bezpieczeństwo publiczne oraz mieszkalnictwo, handel i usługi bytowe o charakterze rzemieślniczym, czyli te usługi, które posiadają charakter ogólnospołeczny.

Częstym rodzajem klasyfikacji infrastruktury jest klasyfikacja według dostępności i sposobu świadczenia usług. $Z$ tego punktu widzenia infrastrukturę można podzielić na obiekty infrastruktury świadczące usługi odbiorcom na zasadzie odpłatności oraz urządzenia i instytucje ogólnie dostępne, które świadczą wszystkim konsumentom usługi niepodlegające pomiarom i odpłatności (Sadowy 1988: 33).

W związku z kryterium odpłatności, J.M. Chmielewski (2001: 149) wyróżnia infrastrukturę społeczną socjalną (dotowaną z budżetu) - oświata, służba zdrowia, opieka społeczna, kultura, bezpieczeństwo i porządek publiczny, zieleń oraz infrastrukturę społeczną komercyjną (samofinansującą się) - rozrywka, turystyka, handel, gastronomia, rzemiosło, banki, ubezpieczenia, grzebalnictwo. 
W przypadku, kiedy z urządzeń infrastruktury korzystają tylko ci użytkownicy, którzy gotowi są zapłacić za świadczone usługi, mamy do czynienia, zgodnie z terminologią w anglosaskiej literaturze ekonomicznej, z tzw. „zasadą wykluczenia". Druga część obiektów i urządzeń infrastruktury to tzw. ogólnie dostępne urządzenia i instytucje infrastruktury, z których korzystanie nie jest związane $\mathrm{z}$ odpłatnością. Korzyści płynące z funkcjonowania tych urządzeń przenikają do bliżej nieokreślonego kręgu odbiorców. Zjawisko to określane jest w literaturze szwajcarskiej jako „przenikanie korzyści” (Sadowy 1988: 33).

Przy definiowaniu infrastruktury społecznej często podkreśla się jej rolę związaną z zaspokojeniem potrzeb człowieka, a więc „doskonaleniem jakości jego życia” (Brol 1995), „,bezpośredniego zaspokojenia potrzeb danego społeczeństwa i umożliwiających właściwe warunki życia ludności" (Miszewski 1973; Palonka 1992; Rogoziński 1993; Kupiec i in. 2004), z „podstawowym czynnikiem, wpływającym na warunki bytowe”. Infrastruktura społeczna dla K. Rogozińskiego (1993: 13) jest „celowo rozmieszczoną siecią urządzeń i instytucji, której zadaniem jest kształtowanie odpowiednich (materialnych) warunków życia i współżycia społecznego, jak również podnoszenie jakości tego życia i współżycia w środowisku społecznym". Według M. Obrębalskiego (2001: 115-116), infrastruktura społeczna spełnia również określone funkcje według przyjętego kryterium: konsumpcyjną i produkcyjną z uwagi na zaspokajanie potrzeb oraz funkcję aktywizującą i modelująco-integrującą z uwagi na przestrzeń społeczno-gospodarczą.

Infrastruktura społeczna odgrywa ważną rolę w rozwoju lokalnym, szczególnie w płaszczyźnie społecznej (m.in. jakość i warunki życia mieszkańców), co jest uwypuklane w wielu definicjach, ale również posiada znaczenie w rozwoju gospodarczym (m.in. wpływa na jakość kapitału społecznego), posiada odwzorowanie $\mathrm{w}$ strukturach funkcjonalno-przestrzennych i w zagospodarowaniu terenu, jak również wywiera wpływ na środowisko przyrodnicze. Zróżnicowane spektrum działalności usługowych zaliczanych do infrastruktury społecznej jest bardzo zdywersyfikowane, co pociąga za sobą różny wpływ na rozwój lokalny (w wyszczególnionych aspektach), a same aktywności charakteryzują się różnym wachlarzem cech (ryc. 1).

Przy całej złożoności problematyki związanej z infrastrukturą społeczną ważne jest, aby zdawać sobie sprawę z bardzo istotnej roli tej infrastruktury, szczególnie w życiu społecznym i gospodarczym, co przekłada się na organizację przestrzeni oraz środowisko przyrodnicze. Należy też pamiętać, że wiele obiektów kwalifikowanych do infrastruktury społecznej nie posiada charakteru komercyjnego, w związku z czym to władza lokalna powinna zabezpieczyć jak najlepsze miejsca ich lokalizacji. 


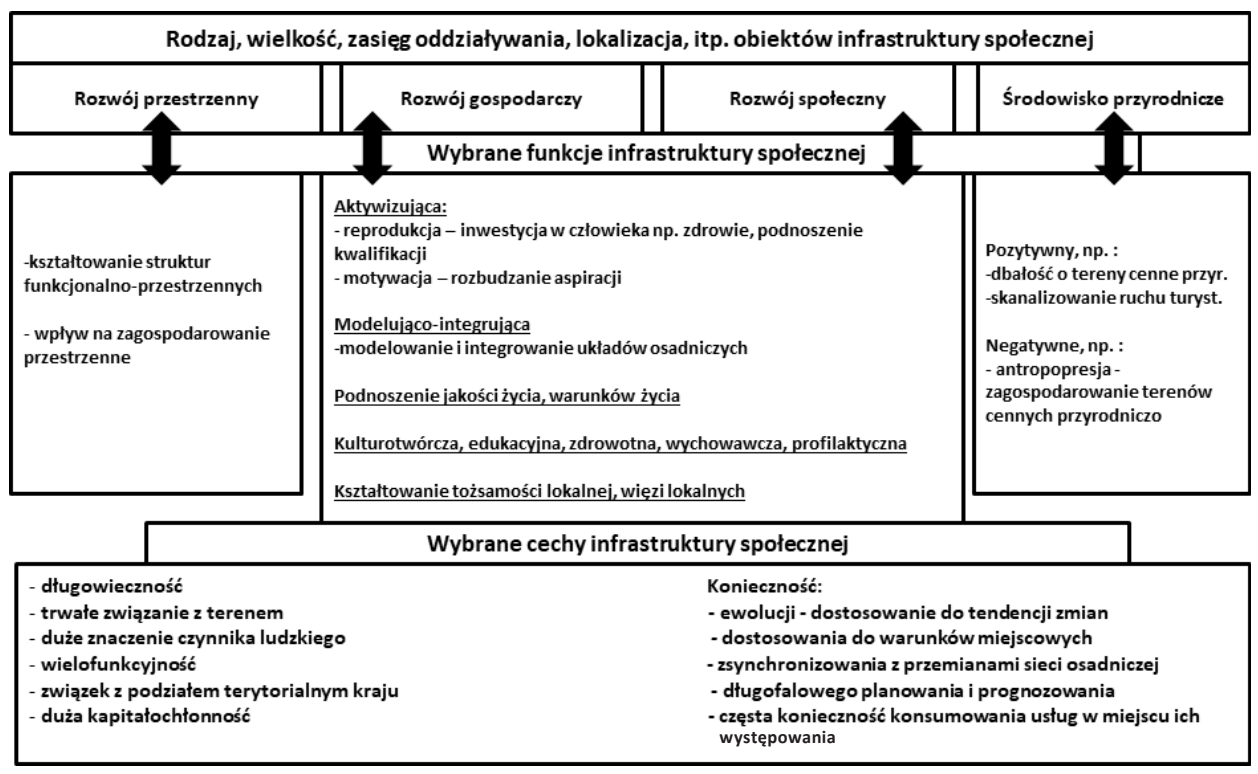

Ryc. 1. Rola infrastruktury społecznej w rozwoju lokalnym

Źródło: opracowanie własne

\subsection{Zmiany w zagospodarowaniu gminy Stryków}

Stryków to gmina miejsko-wiejska położona w centralnej Polsce, w województwie łódzkim, w powiecie zgierskim - niedaleko Łodzi. Swoim zasięgiem obejmuje obszar miasta Strykowa $\left(8,15 \mathrm{~km}^{2}\right)$ oraz przyległe tereny wiejskie $\left(149,75 \mathrm{~km}^{2}\right)$. Tereny wiejskie podzielone są na 35 sołectw, w tym 42 wsie, a teren miasta na 4 osiedla $^{1}$. Obszar gminy zamieszkuje 12475 osób, z tego 3487 w mieście Strykowie (GUS 2017). Najludniejszą wsią są Bratoszewice, której liczba mieszkańców przekracza 1100 osób. W gminie dominują wsie liczące od 185 do 367 osób, a są to m.in. Koźle, Osse, Ciołek, Wola Błędowa, Wyskoki, Rokitnica, Niesułków, Lipka, Dobra itp. Liczba ludności w najmniejszych wsiach mieści się w przedziale od 70 do 184 osób, są to m.in. wsie takie, jak Warszewice, Anielin, Sierżnia, Bartolin, Nowostawy Górne, Dobieszków, Stary Imielnik. W gminie Stryków w skład jednego sołectwa wchodzi najczęściej tylko jedna wieś. Nie jest to jednak regułą, ponieważ występuje tu również kilka dużych sołectw, które obejmują dwie bądź trzy wsie - są to m.in. Tymianka, Wrzask, Kiełmia, Warszewice. Od 1995 roku liczba ludności w mieście Strykowie sukcesywnie spada (-1141 os.), natomiast tereny wiejskie notują bilans dodatni (+714 os.).

${ }^{1}$ Osiedla miasta Stryków: Osiedle im. M. Kopernika - Zacisze, Osiedle im. Stefana Batorego - Kolejowa, Osiedle Centrum, Osiedle Wschód. 
Na podstawie danych z międzynarodowego programu CORIN (CO-oRdination of INformation on Environment) (CLC 1990 oraz CLC 2012) stworzono mapy przedstawiające pokrycie terenu w 1990 i 2012 roku. W 1990 roku w gminie przeważały grunty orne (62\% powierzchni gminy). Lasy zajmowały $13 \%$ ogółu powierzchni gminy, łąki, pastwiska i tereny z dużym udziałem roślinności naturalnej $-12,5 \%$ ogółu powierzchni gminy, złożone systemy upraw i działek - 11,5\% ogółu powierzchni gminy. Najmniejszy odsetek zajmowała zabudowa miejska luźna $-1 \%$ powierzchni gminy (ryc. 2 ).

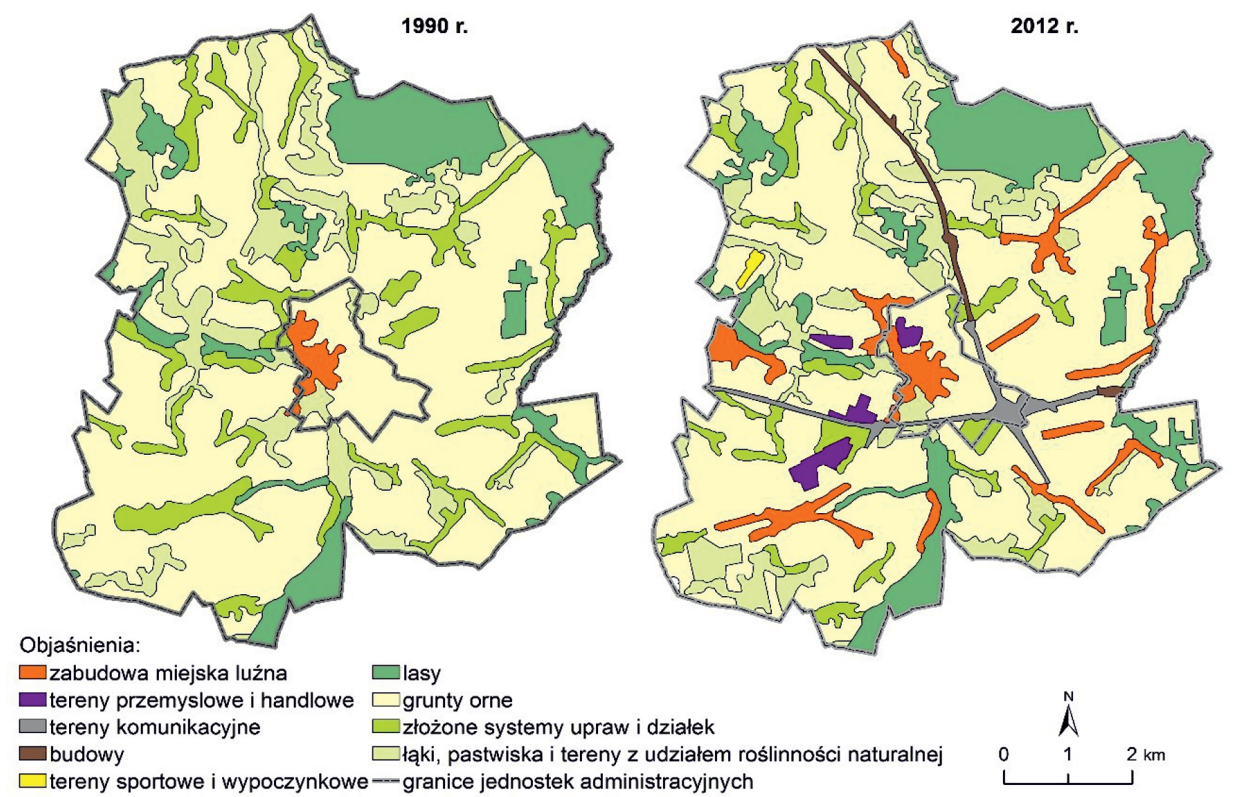

Ryc. 2. Pokrycie terenu w gminie Stryków w 1990 i 2012 roku

Źródło: opracowanie własne na podstawie danych z http://land.copernicus. eu/pan-european/corine-land-cover/view.

W 2012 roku powierzchnia lasów zwiększyła się do 14,5\%, a zabudowy do $6,2 \%$ ogółu. Jednak największy odsetek powierzchni gminy nadal zajmowały grunty orne $(58,2 \%)$, chociaż ich powierzchnia zmniejszyła się w stosunku do tej z roku 1990. Ubytek wielkości zajmowanej powierzchni widoczny był także w przypadku łąk, pastwisk i terenów z dużym udziałem roślinności naturalnej (11,3\% powierzchni gminy) oraz złożonych upraw i działek (6\% powierzchni gminy). Pojawiły się natomiast nowe sposoby użytkowania ziemi. Zajmowały one odpowiednio: tereny przemysłowe i handlowe $(1,2 \%)$, tereny komunikacyjne $(1,6 \%)$, tereny sportowe i wypoczynkowe $(0,2 \%)$ oraz budowy $(0,8 \%)$ ogółu powierzchni gminy. 
Gmina Stryków jest obecnie jedną z najlepiej skomunikowanych gmin w województwie łódzkim i w Polsce. Kluczowym gospodarczym atutem gminy jest jej położenie przy głównym węźle komunikacyjnym autostrad A1 i A2. Przez gminę przebiega również linia kolejowa Łódź-Łowicz, wraz z bocznicą do załadunku pociągów towarowych. Związana jest z tym tendencja przeznaczania coraz większej powierzchni terenów gminy pod inwestycje, które powodują, że gmina Stryków traci swój rolniczy charakter na korzyść pozarolniczej działalności gospodarczej.

Na terenie gminy Stryków działają znaczące światowe firmy ze Szwajcarii, Wielkiej Brytanii, Niemiec, Finlandii, Holandii, USA czy Francji. Ich inwestycje zajmują ponad 350 ha z całkowitej powierzchni gminy. Dodatkowo, na nowe inwestycje przeznaczono 1062 ha terenów gminy Stryków. Są one położone w 12 sołectwach oraz mieście Stryków. Zajmują odpowiednio: 8 ha w sołectwie Dobra, 20 ha w sołectwie Warszewice, po 25 ha w sołectwach Smolice i Tymianka, 50 ha w sołectwie Bratoszewice, po 70 ha w sołectwach Sosnowiec Pieńki i Rokitnica, 80 ha w sołectwie Kalinów, 84 ha w sołectwie Nowostawy Górne, 98 ha w sołectwie Sosnowiec, 125 ha w sołectwie Wola Błędowska, 131 ha w sołectwie Zelgoszcz oraz 276 ha w mieście Stryków².

Inwestycje na terenach sołectw są działaniem pożądanym, gdyż tworzone są nowe miejsca pracy, a gmina otrzymuje dodatkowe wpływy do budżetu, m.in. z podatku od nieruchomości. Jednak w przypadku miasta Stryków, 276 ha nowych obszarów inwestycyjnych całkowicie zablokuje możliwość innego wykorzystania powierzchni, np. na cele mieszkaniowe czy usługowe oraz może wpływać na dalszą depopulację miasta.

Poniżej zamieszczono mapę przedstawiającą prognozowaną wielkość obszarów inwestycyjnych w gminie Stryków (ryc. 3).

W strukturze podmiotów zarejestrowanych w REGON (2007), w 2016 roku w całej gminie Stryków przeważały podmioty gospodarcze sekcji G, czyli zajmujące się handlem hurtowym i detalicznym oraz naprawą pojazdów samochodowych - w mieście Stryków podmioty tego typu stanowiły $26,6 \%$ ogółu, natomiast na terenach wiejskich gminy Stryków 23,6\% ogółu. W Strykowie duży udział w ogólnej strukturze miały również podmioty gospodarcze z sekcji: $\mathrm{C}$ - przetwórstwo przemysłowe (11,9\%), S - pozostała działalność usługowa, T - gospodarstwa domowe zatrudniające pracowników, gospodarstwa domowe produkujące wyroby i świadczące usługi na własne potrzeby, U - organizacja i zespoły eksterytorialne (w sumie $11,3 \%$ ), F - budownictwo (11\%) oraz Q - opieka zdrowotna i pomoc społeczna $(8,5 \%)$. W przypadku terenów wiejskich gminy Stryków, podobnie jak w Strykowie, duży udział w ogóle podmiotów miały te z sekcji C (14,6\%) i sekcji F (12,6\%). Dodatkowo, na terenach wiejskich wyróżnić można duży udział podmiotów z sekcji $\mathrm{H}$ - transport i gospodarka magazynowa $(9,9 \%)$ oraz $\mathrm{M}$ - działalność profesjonalna, naukowa i techniczna (9,2\%) (ryc. 4,5$)$.

\footnotetext{
${ }^{2}$ Strategia Rozwoju Gminy Stryków na lata 2014-2020, 2013, UMiG, Stryków.
} 


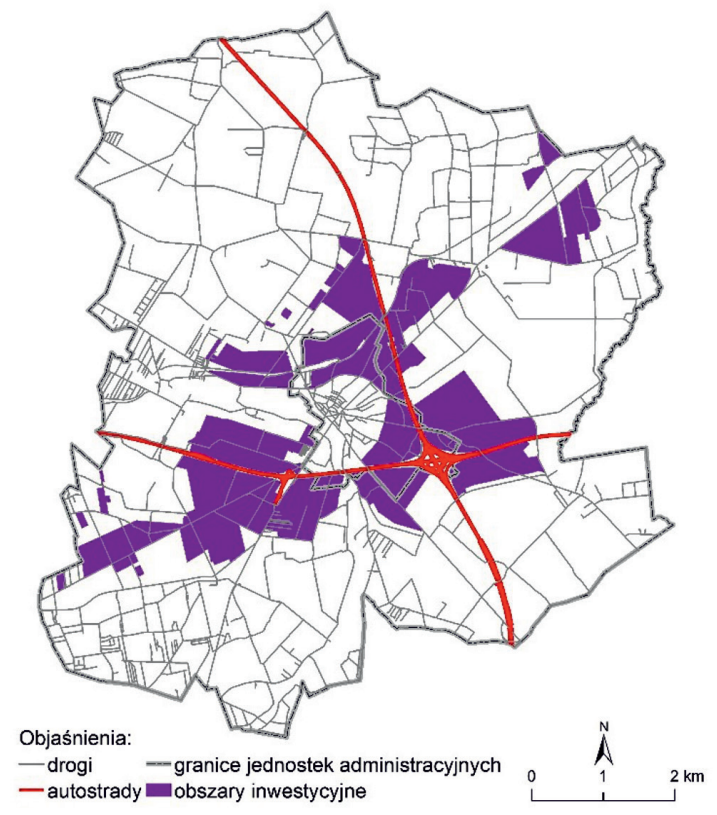

Ryc. 3. Prognozowana wielkość obszarów inwestycyjnych w gminie Stryków Źródło: opracowanie własne na podstawie Studium uwarunkowań i kierunków... (2008) oraz danych z http://www.codgik.gov.pl.
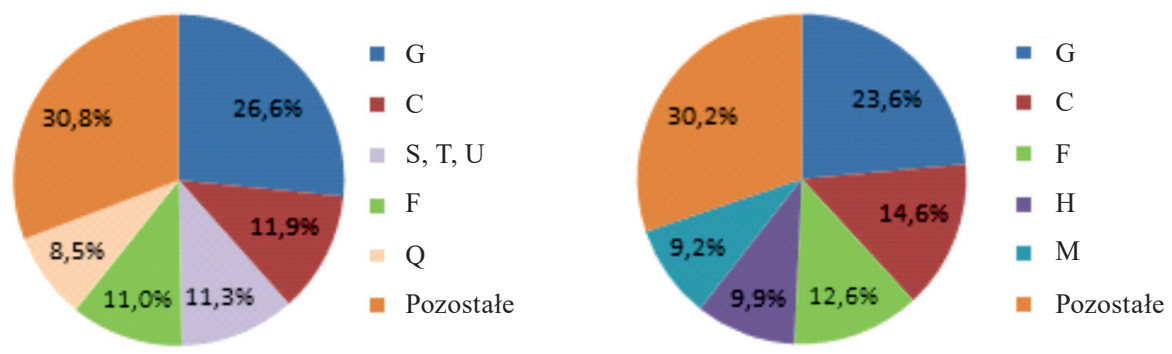

Objaśnienia: C - przetwórstwo przemysłowe, $\mathrm{G}$ - handel hurtowy i detaliczny; naprawa pojazdów samochodowych, włączając motocykle, F - budownictwo, H - transport i gospodarka magazynowa, M-działalność profesjonalna, naukowa i techniczna, Q- opieka zdrowotna i pomoc społeczna, S-pozostała działalność usługowa, T - gospodarstwa domowe zatrudniające pracowników; gospodarstwa domowe produkujące wyroby i świadczące usługi na własne potrzeby, $\mathrm{U}$ - organizacje i zespoły eksterytorialne

Ryc. 4. Struktura podmiotów Gospodarki Narodowej wpisanych do rejestru REGON w mieście Stryków w 2016 roku

Źródło: BDL (2016).
Ryc. 5. Struktura podmiotów Gospodarki Narodowej wpisanych do rejestru REGON na terenach wiejskich gminy Stryków w 2016 roku

Źródło: BDL (2016). 
Pod względem struktury podmiotów Gospodarki Narodowej związanych z infrastrukturą społeczną wpisanych do rejestru REGON zarówno w mieście Stryków, jak i na terenach wiejskich największy odsetek stanowią działalności społeczno-gospodarcze należące do sekcji G (handel hurtowy i detaliczny, naprawy pojazdów samochodowych, włączając motocykle) - odpowiednio 46,3\% i 42,3\% punktów usługowych. Zaliczamy do nich m.in. różnego rodzaju sklepy spożywcze, przemysłowe itp., których w Strykowie jest zlokalizowanych $67^{3}$, a na pozostałych terenach gminy -35 . W mieście dużym udziałem charakteryzują się również sekcja Q - opieka zdrowotna i pomoc społeczna (14,8\%) - na terenach wiejskich to tylko 5,6\%, co świadczy o koncentracji usług zdrowotnych w ,stolicy” gminy. Podmiotów z sekcji M - działalność profesjonalna, naukowa i techniczna jest więcej na terenach wiejskich (odpowiednio w Strykowie - 7,4\%, w sołectwach 16,7\%), co wynika z faktu, że na terenach wiejskich jest więcej szkół podstawowych, a w Bratoszewicach działa również szkoła średnia. Udział pozostałych podmiotów usługowych jest porównywalny na terenach miejskich i wiejskich (ryc. 6).

A

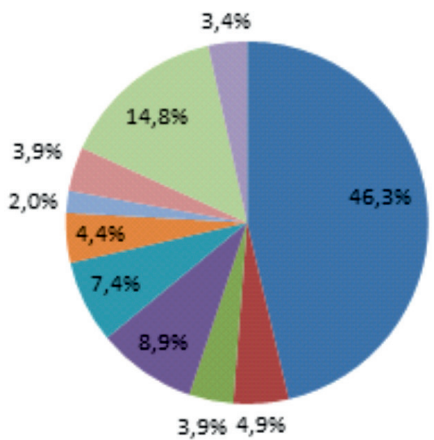

$\mathrm{B}$

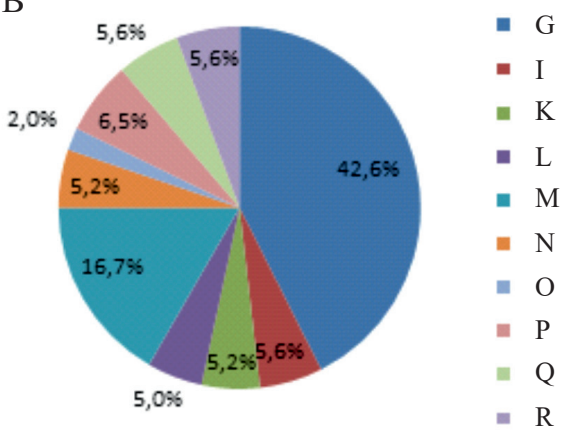

Objaśnienia: G - handel hurtowy i detaliczny; naprawa pojazdów samochodowych, włączając motocykle, I - działalność związana z zakwaterowaniem i usługami gastronomicznymi, $\mathrm{K}$ - działalność finansowa i ubezpieczeniowa, L-działalność związana z obsługą rynku nieruchomości, $\mathrm{M}$-działalność profesjonalna, naukowa i techniczna, $\mathrm{N}$ - działalność w zakresie usług administrowania i działalność wspierająca, $\mathrm{O}$ - administracja publiczna i obrona narodowa; obowiązkowe zabezpieczenia społeczne, $\mathrm{P}$ - edukacja, $\mathrm{Q}$ - opieka zdrowotna i pomoc społeczna, $\mathrm{R}$ - działalność związana z kulturą, rozrywką i rekreacją

Ryc. 6. Struktura podmiotów Gospodarki Narodowej związanych z infrastrukturą społeczną wpisanych do rejestru REGON w 2016 roku A - w mieście Stryków, B - na terenach wiejskich gminy Stryków

Źródło: BDL (2016).

${ }^{3}$ Dane dotyczące obiektów infrastruktury społecznej pochodzą z inwentaryzacji przeprowadzonej na terenie gminy Stryków w czerwcu 2016 roku oraz z Geoportalu Województwa Łódzkiego (http://geoportal.lodzkie.pl, dostęp: 28.02.2017). 
Infrastruktura społeczna w gminie miejsko-wiejskiej Stryków rozmieszczona jest bardzo nierównomiernie. Największa liczba obiektów użyteczności publicznej zlokalizowana jest w centrum gminy, czyli w mieście Stryków. Najlepiej zaopatrzonym w infrastrukturę społeczną sołectwem jest położone w północno-wschodniej części gminy - sołectwo Bratoszewice, w którym zlokalizowanych jest 9 różnego rodzaju obiektów oraz sołectwo Dobra, w którym znajduje się 5 obiektów. Spośród 35 sołectw obszaru wiejskiego gminy Stryków, aż w 17 nie jest zlokalizowany żaden obiekt infrastruktury społecznej (ryc. 7). Lokalizacja ich uzależniona jest w znacznej mierze od wielkości należących do gminy sołectw - duże powierzchniowo jednostki zamieszkuje większa liczba osób, a zatem zapotrzebowanie na tego typu usługi jest większe. Natomiast mniejsze sołectwa mają ograniczony dostęp do usług z zakresu infrastruktury społecznej.

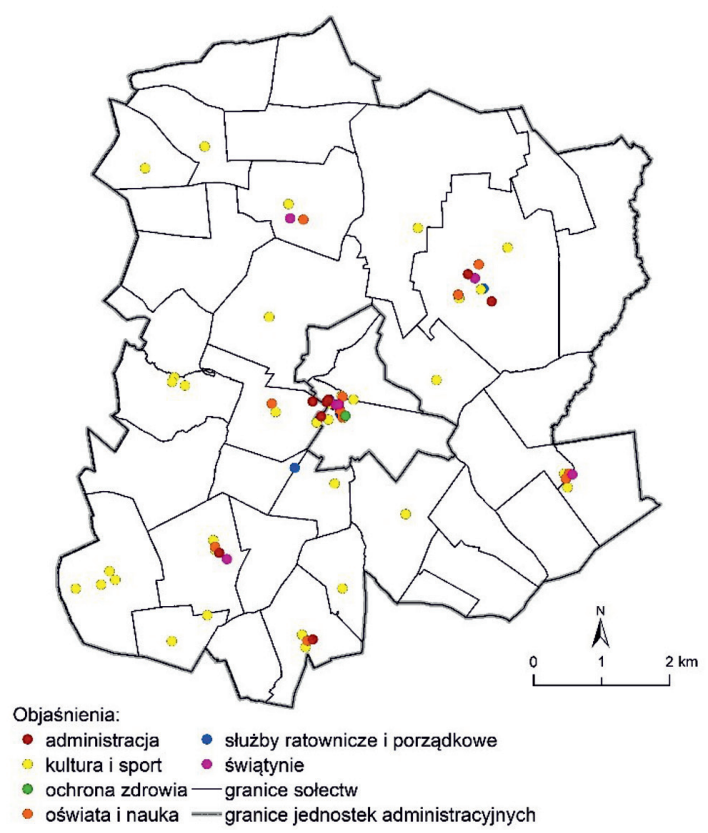

Ryc. 7. Rozmieszczenie obiektów infrastruktury społecznej w gminie Stryków

Źródło: opracowanie na podstawie inwentaryzacji oraz Geoportalu Województwa Łódzkiego.

\subsection{Inwestycje samorządowe w oczach mieszkańców gminy}

Władze gminy Stryków na swoim terenie prowadzą intensywną działalność inwestycyjną, głównie z zakresu inwestycji infrastrukturalnych. W związku z powyższym istotnym jest ustalenie jak na takie działania zapatrują się mieszkańcy tej gminy. W przypadku inwestycji, które zostały przeprowadzone w gminie 
Stryków w ciągu ostatnich 5 lat, aż 81\% (400 os.) zauważa takie działania i je wskazało, tylko 19\% (94 os.) nie wypowiedziało się w tej kwestii - nie wskazało działań władz gminy lub uważa, że takiego nie ma (brak, trudno powiedzieć, żadne; nie ma takich, nie wiem). Według mieszkańców, władze głównie przeprowadziły działania związane $\mathrm{z}$ drogami, w tym m.in. utwardzenie bocznych uliczek, modernizacje ulic, polepszenie stanu dróg, wymianę asfaltu $(51,2 \%$ respondentów wymieniło tego typu działania). Innymi inwestycjami z zakresu infrastruktury drogowej wskazywanymi przez ankietowanych były: chodniki (46 os.) i oświetlenie dróg (20 os.). Pojedyncze osoby (poniżej 10 osób) wskazały ponadto również na przystanki, dworzec PKP i ścieżki rowerowe. Na drugim miejscu zauważalne jest przygotowanie terenów pod nowe inwestycje i budowa magazynów (53 os.). Z zakresu budowy i modernizacji infrastruktury technicznej dostrzeżono też inwestycje obejmujące sieć kanalizacyjną (33 os.), wodociągową (13 os.) i gazową (4 os.).

Mieszkańcy mieli większe trudności ze wskazaniem inwestycji z zakresu infrastruktury społecznej. Pod tym względem największa liczba respondentów wymieniła: place zabaw (30 os.), boiska sportowe ( 25 os.), zagospodarowanie rekreacyjno-wypoczynkowe terenu nad zalewem w Strykowie, w tym m.in. skatepark (24 os.), świetlice miejskie i wiejskie (16 os.), inwestycje w obiekty oświatowe (15 os.) oraz budowę mieszkań socjalnych (9 os.). Nieliczni ankietowani (poniżej 10 osób) wymieniali dodatkowo osiedlowe siłownie, odnowę rynku i parku w Strykowie czy też modernizację OSP (ryc. 8).

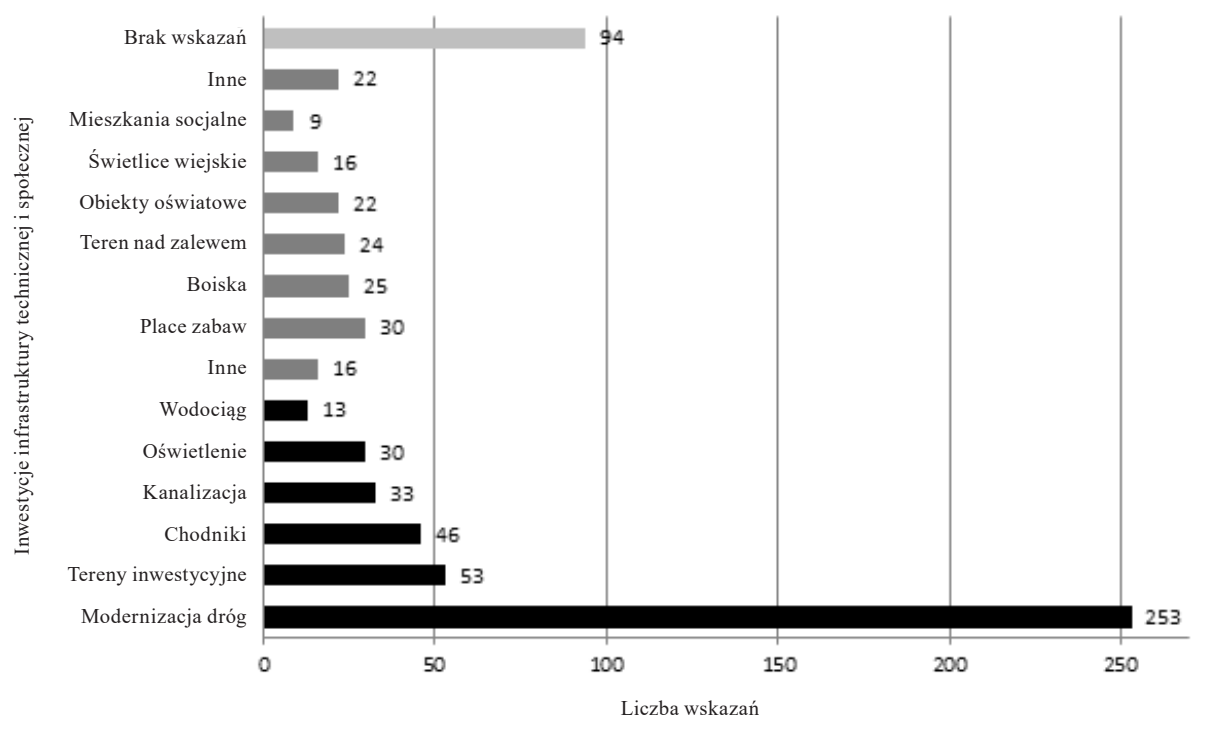

Ryc. 8. Najważniejsze inwestycje jakie w ciągu ostatnich 5 lat według mieszkańców przeprowadziły władze gminy Stryków

Źródło: badania ankietowe. 
Osoby badane najczęściej wskazywały inwestycje, które zostały przeprowadzone w ich miejscu zamieszkania lub w pobliżu. Należy też zwrócić uwagę, że respondenci nie zawsze odróżniają inwestycje lokalne - samorządowe, za które odpowiadają władze gminy, od inwestycji prowadzonych przez inne podmioty. Przykładem może być częste wymienianie autostrad jako inwestycji samorządowych (30 os.) lub budowa magazynów (25 os.). Jak wynika z powyższego wykresu, respondenci częściej zauważali inwestycje samorządowe z zakresu infrastruktury technicznej, a przede wszystkim związane z drogami niż te zaliczone do infrastruktury społecznej.

Według mieszkańców gminy Stryków, inwestycje na terenie gminy będą potrzebne w przyszłości - wskazało tak $86,4 \%$ respondentów (427 os.). Nadal występuje zapotrzebowanie na inwestycje z zakresu infrastruktury technicznej, szczególnie budowy chodników lub poprawy ich jakości (73 wskazania), modernizacji i remontu dróg, w tym budowy obwodnicy Strykowa (53 wskazania), ważne jest skanalizowanie, zwodociągowanie i zgazyfikowanie obszarów, które jeszcze do chwili obecnej nie doczekały się takiej inwestycji. Respondenci zwracali uwagę na brak ścieżek rowerowych, zbyt małą liczbę połączeń komunikacyjnych, braki w niektórych miejscach oświetlenia oraz na brak dostępu do Internetu. W kategorii „,inne” niektóre osoby (poniżej 10 osób) wymieniały m.in. budowę ekranów dźwiękoszczelnych (zbyt duży hałas drogowy), budowę oczyszczalni ścieków oraz dofinansowanie przydomowych oczyszczalni ścieków, lokalizowanie progów zwalniających i budowę parkingów (ryc. 9).

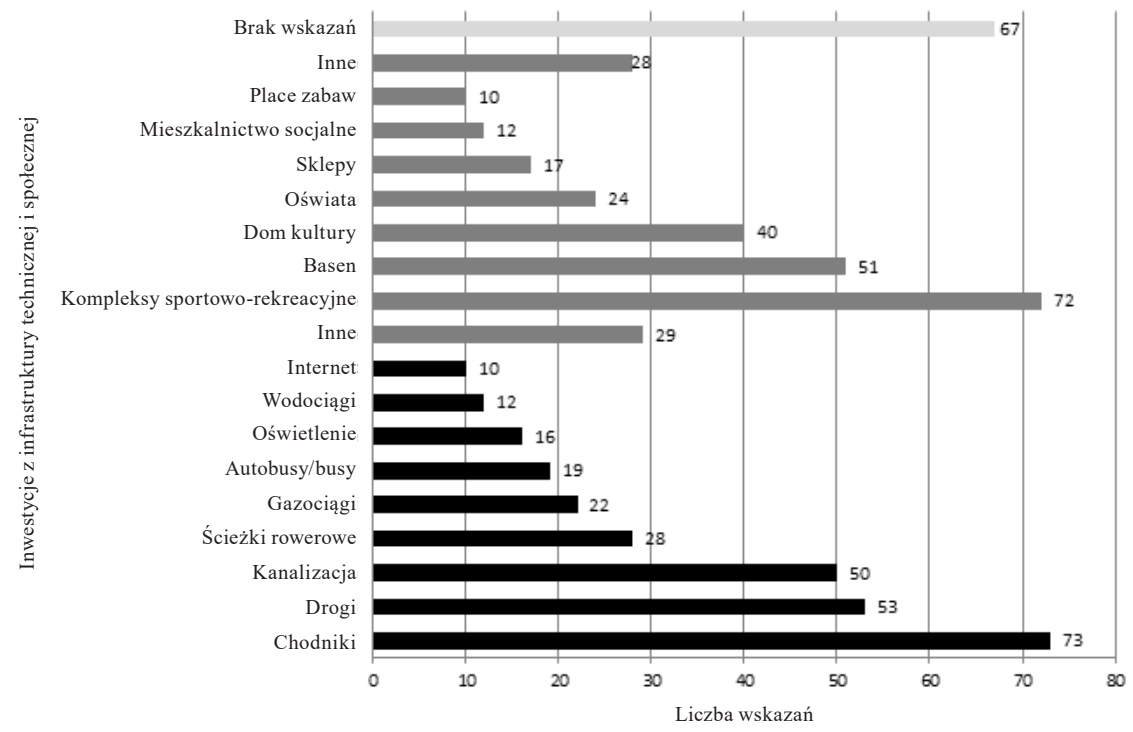

Ryc. 9. Najważniejsze inwestycje jakie według mieszkańców powinny władze gminy Stryków zrealizować w najbliższym czasie

Źródło: badania ankietowe. 
Mieszkańcy gminy zauważają również braki w infrastrukturze społecznej i oczekują na podjęcie działań w tym zakresie. Najwięcej osób wskazało na konieczność zorganizowania na terenie gminy kompleksów sportowo-rekreacyjnych, w tym z halą sportową (72 os.). W takim kompleksie mógłby się znaleźć basen. Ponieważ basen był wymieniany często niezależnie od takiego kompleksu, wyodrębniono go jako osobną kategorię (51 os., niezależnie). Obok obiektów sportowych wskazywano również na budowę (często w nowej lokalizacji) Domu Kultury (40 os.), przeprowadzanie dalszych inwestycji w budynki oświaty ( $24 \mathrm{os}$.), budowę sklepów (głównie w miejscowościach, gdzie tego typu obiektów nie ma) (17 os.) oraz na budownictwo socjalne (12 os.), a także dalszą budowę placów zabaw dla dzieci (10 os.). Kilka osób (8os.) m.in. zwróciło uwagę na konieczność budowy szkoły ponadgimnazjalnej. Pojedyncze osoby (poniżej 10 os.) wymieniły również kino, dalsze prace nad zalewem - uzupełnienie oferty i powiększenie plaży oraz na budowę świetlic wiejskich (ryc. 9).

\subsection{Dostępność infrastruktury społecznej w oczach mieszkańców}

Podczas badania ankietowego respondenci zamieszkujący gminę Stryków zostali poproszeni o ocenę (w skali od 1 do 5) dostępności do 11 różnych obiektów infrastruktury społecznej. Oceny zbiorcze zawierały się w przedziale od 2,6 do 3,9 punktu, czyli były na poziomie średnim lub dobrym. Dostępność żadnego $\mathrm{z}$ wymienionych obiektów nie została oceniona jako bardzo dobra.

Mieszkańcy miasta Styków ocenili wyżej, niż mieszkańcy terenów wiejskich gminy, dostępność do placówek handlowych (3,9 pkt. - miasto/3,6 pkt. - wieś), terenów rekreacyjnych $(3,2 / 3,1)$, obiektów sportowych $(2,9 / 2,8)$, placów zabaw dla dzieci $(3,9 / 3,0)$ oraz zagospodarowania otoczenia zalewu $(3,9 / 3,5)$. Natomiast mieszkańcy terenów wiejskich wyżej ocenili dostępność do placówek służby zdrowia (3,4 pkt. - miasto/3,5 pkt. - wieś), placówek szkolno-oświatowych $(3,2 / 3,3)$, możliwości spędzania czasu wolnego $(3,0 / 3,2)$ oraz ofertę Domu Kultury $(3,5 / 3,3)$. W przypadku oceny dostępności oferty Domu Kultury, aż 59,2\% mieszkańców terenów wiejskich nie oceniło jej, ponieważ nie korzystają z propozycji ofertowej świadczonej w tym obiekcie. Na tym samym poziomie, przez obie grupy respondentów, została oceniona dostępność do placówek gastronomicznych (po 2,6 pkt.) oraz pozostałych placówek usługowych (po 3,1 pkt.).

Większość różnic punktowych jest niewielka, dlatego też można wnioskować, że ankietowani z obu obszarów, pomimo różnych odległości do obiektów infrastruktury społecznej, uważają je za ogólnodostępne. Znaczące różnice widoczne są jednak w przypadku dostępu do placów zabaw dla dzieci oraz placówek handlowych. Ankietowani pochodzący z terenów wiejskich swoimi odpowiedziami sugerują, że właśnie tych obiektów infrastruktury brakuje w ich otoczeniu, władze gminy powinny więc skoncentrować swoje działania na próbie zaspokojenia potrzeb społecznych w tym zakresie (ryc. 10). 


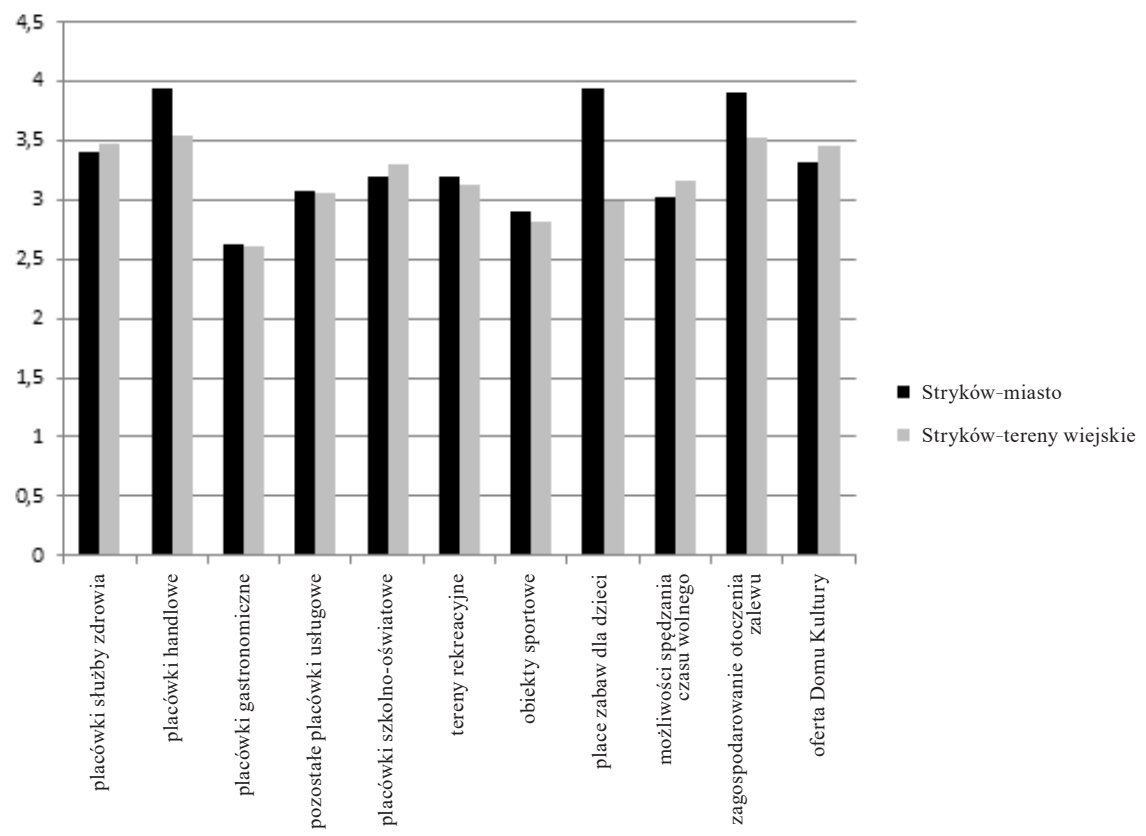

Ryc. 10. Ocena dostępności obiektów infrastruktury społecznej według miejsca zamieszkania (skala: 1-5)

Źródło: badania ankietowe.

Dostępność do obiektów infrastruktury społecznej była wyżej oceniana przez kobiety. Mężczyźni przyznali więcej punktów jedynie w przypadku placów zabaw dla dzieci, placówek służby zdrowia oraz terenów rekreacyjnych. Najlepiej oceniana przez kobiety i mężczyzn była dostępność do zagospodarowania otoczenia zalewu (3,9 pkt. kobiety i 3,7 pkt. mężczyźni) oraz do placówek handlowych (3,7 pkt. kobiety i 3,6 pkt. mężczyźni), natomiast najgorzej do placówek gastronomicznych (po 2,8 pkt.) oraz obiektów sportowych $(3,1$ pkt. kobiety i 3 pkt. mężczyźni) (ryc. 11).

Analiza wyników ankiety pozwoliła również na ocenę dostępności 11 wybranych obiektów ze względu na wiek respondentów. Wszyscy respondenci najwyżej ocenili dostępność do zagospodarowania otoczenia zalewu (4 pkt. osoby poniżej 24 lat; 3,7 pkt. osoby w wieku 25-44 lata; 3,8 pkt. osoby w wieku 45-64 lata oraz 3,9 osoby po 65 roku życia), natomiast najgorzej dostępność do obiektów gastronomicznych (odpowiednio: 2,$7 ; 2,7 ; 3,0 ; 2,7$ pkt.) oraz obiektów sportowych (odpowiednio: 2,8; 3,0;3,2; 3,2 pkt.). Najmłodsi respondenci niezadowoleni byli również z dostępności do terenów rekreacyjnych oraz innych możliwości spędzania wolnego czasu (po 3 pkt.) (ryc. 12). 


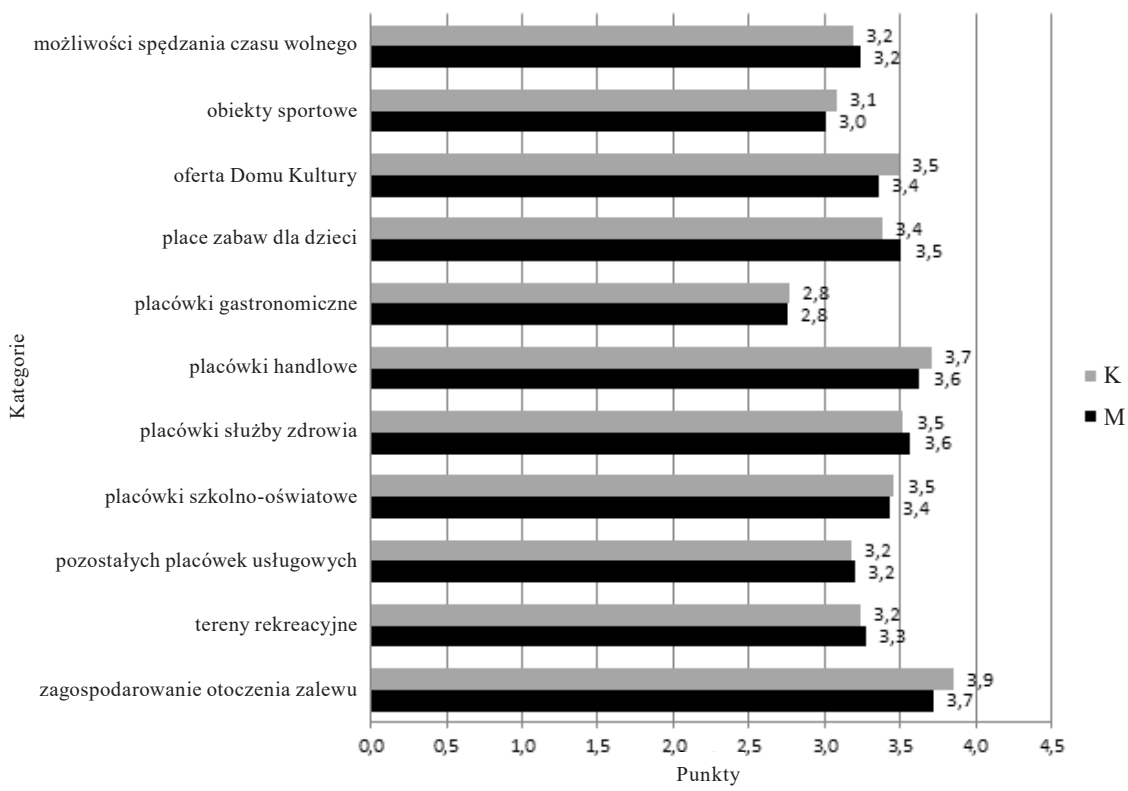

Ryc. 11. Ocena dostępności obiektów infrastruktury społecznej według płci (skala: 1-5) Źródło: badania ankietowe.

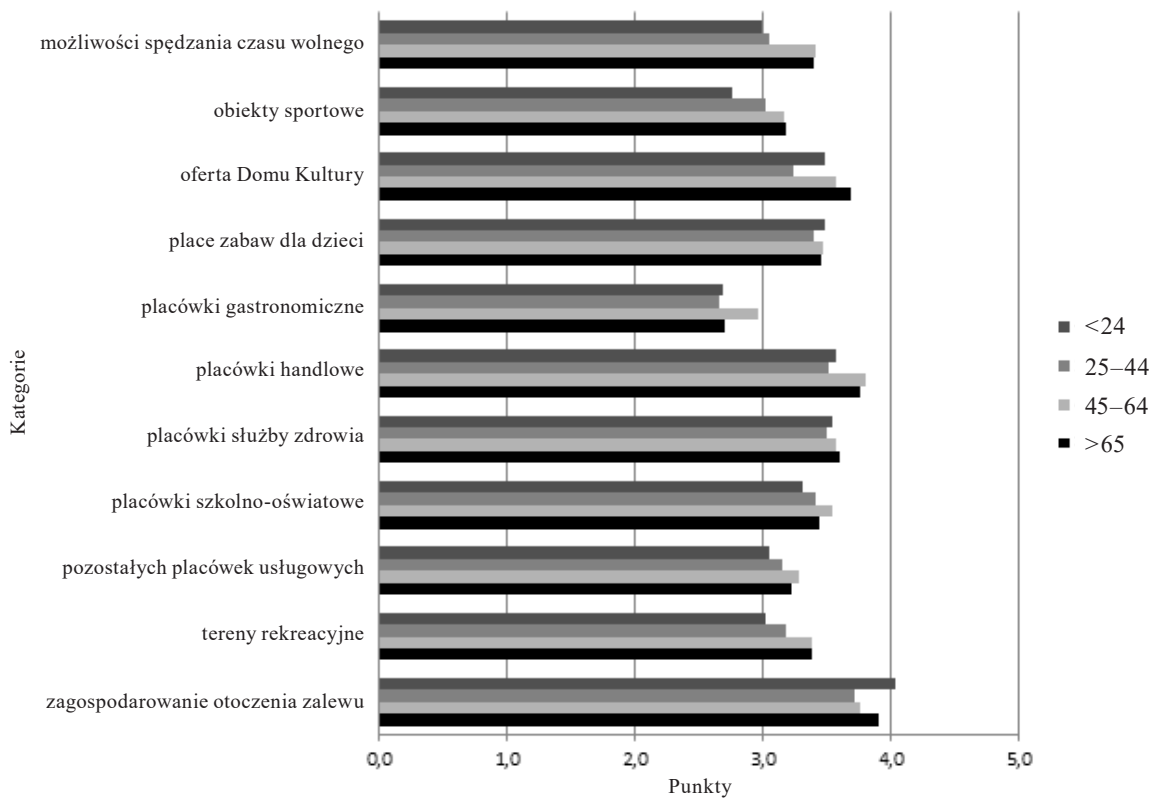

Ryc. 12. Ocena dostępności obiektów infrastruktury społecznej według grup wiekowych (skala: 1-5)

Źródło: badania ankietowe. 
Niewielkie zróżnicowanie punktacji w różnych grupach wiekowych świadczyć może o ogólnym zapotrzebowaniu na wzrost liczby konkretnych obiektów infrastruktury społecznej. Jedynie wśród osób najmłodszych można zauważyć potrzebę rozwoju tych obiektów, które bezpośrednio związane są z wypełnianiem czasu wolnego i aktywnością fizyczną.

Interesującym jest także fakt, że wraz z wiekiem zadowolenie $\mathrm{z}$ poziomu dostępności do obiektów infrastruktury społecznej wzrasta. Najbardziej zadowoloną grupą wiekową są osoby miedzy 45 a 65 rokiem życia, czyli te które najprawdopodobniej mają ustabilizowaną sytuację życiową oraz zawodową.

\subsection{Wnioski}

W przypadku gminy Stryków widoczne są głównie inwestycje z zakresu infrastruktury technicznej. Szczególnie mieszkańcy zauważali te związane z infrastrukturą drogową oraz gospodarką magazynową (choć często mylili inwestycje samorządowe z tymi realizowanymi przez inne podmioty). Dużo słabiej na tym tle wypada infrastruktura społeczna, gdzie głównie spostrzeżono budowę placów zabaw, modernizację sal gimnastycznych oraz nowe zagospodarowanie terenów nad zalewem w Strykowie. Słabo została tym samym oceniona dostępność do obiektów infrastruktury społecznej - bardzo uogólniając na dostateczny z plusem. Przy tak dobrze rozwijającej się gospodarczo gminie jest to ocena niezbyt wysoka. Głównymi bolączkami gminy jest niewystarczająca oferta obiektów służących do spędzania czasu wolnego, a szczególnie brak terenów sportowo-rekreacyjnych oraz placówek gastronomicznych.

Mieszkańcy nadal widzą braki w rozwoju infrastrukturalnym gminy wskazując szczególnie na kłopoty z brakiem chodników, ścieżek rowerowych oraz na niedokończoną obwodnicę Strykowa. $Z$ zakresu infrastruktury technicznej nadal wnoszone są postulaty o dalsze prace z zakresu drogownictwa - dokończenie rozpoczętych prac (modernizacja nawierzchni, oświetlenie), rozbudowa sieci wodno-kanalizacyjnej, gazowniczej. Najczęściej te wskazania mają bardzo lokalny charakter (niektóre wsie) i są związane z bezpośrednim sąsiedztwem obiektów uciążliwych, np. dyskomfortowym hałasem drogowym.

Dużo większe spektrum koniecznych do zrealizowania inwestycji samorządowych było wskazywane z zakresu infrastruktury społecznej. Lokalnej społeczności szczególnie brakuje kompleksu sportowo-rekreacyjnego, w tym głównie krytego basenu, nowego z ,prawdziwego zdarzenia” Domu Kultury o lepszej ofercie programowej.

Z przeprowadzonych badań wynika, że dynamiczny rozwój gospodarczy nie zawsze idzie w parze z oczekiwaniami społecznymi. Przed władzami gminy nadal stoją rozliczne wyzwania, szczególnie te związane z rozwojem infrastruktury społecznej - infrastruktury, która w ewidentny sposób wpływa na postrzeganie jakości życia przez mieszkańców na danym terenie. 


\section{Literatura}

Błaszczyk M., Kłopot S.W., Pluta J., 2010, Stare i nowe problemy społeczne wielkiego miasta. Socjologiczne studium konsumpcji na przykładzie Wrocławia, Wydawnictwo Naukowe Scholar, Warszawa.

Borsa M., 2007, Podstawy urbanistyki i planowania przestrzennego, Materiały dla studentów Szkoły Głównej Handlowej w Warszawie, Wersja robocza, Warszawa.

Brol R., 1995, Gospodarka lokalna, Wrocław.

Budner W., 2003, Lokalizacja przedsiębiorstw. Aspekty ekonomiczno-przestrzenne i środowiskowe, Wydawnictwo Akademii Ekonomicznej, Poznań.

Chmielewski J.M., 2001, Teoria urbanistyki w projektowaniu i planowaniu miast, Oficyna Wydawnicza Politechniki Warszawskiej, Warszawa.

Dolata M., Łuczka-Bakuła W., 2005, Stan i kierunki rozwoju infrastruktury gospodarczej obszarów wiejskich Wielkopolski, Wydawnictwo Akademii Rolniczej im. Augusta Cieszkowskiego w Poznaniu, Poznań.

Kapusta F., 2012, Poziom infrastruktury technicznej i społecznej jako indykator i stymulator rozwoju regionalnego, „Nierówności Społeczne a Wzrost Gospodarczy”, 29: 315-325.

Kołodziejczyk D., 2014, Infrastruktura w rozwoju społeczno-gospodarczym gmin w Polsce, Prace Naukowe Uniwersytetu Ekonomicznego we Wrocławiu, 360: 198-207.

Kozłowski W., 2012, Zarządzanie gminnymi inwestycjami infrastrukturalnymi, Wydawnictwo Difin, Warszawa.

Kroszel A., 1990, Infrastruktura społeczna w polityce społecznej, Wydawnictwo Instytutu Śląskiego, Opole.

Kupiec L., Gołębiowska A., Wyszkowska D., 2004, Gospodarka przestrzenna - t. 6: Infrastruktura społeczna, Wydawnictwo Uniwersytetu w Białymstoku, Białystok.

Mikołajewicz Z., 1991, Inwestycje jako czynnik kształtujacy zasoby infrastruktury spoŁecznej, Opole.

Mikołajewicz M., 1992, Gospodarowanie zasobami środków trwałych infrastruktury społecznej, Wydawnictwo Instytutu Śląskiego, Opole.

Mirowski W., 1996, Studia nad infrastrukturą wsi polskiej. Wyposażenie obszarów w infrastrukturę społeczna, Polska Akademia Nauk - Instytut Rozwoju Wsi i Rolnictwa, 3, Warszawa.

Miszewski B., 1973, Postęp społeczny a infrastruktura społeczna, PWE, Warszawa.

Naumowicz K., 1992, Zagadnienia ogólne: skrypt dla studentów kierunku ekonomika i organizacja obrotu towarowego i ustug, Wydawnictwo Uniwersytetu Szczecińskiego, Szczecin.

Obrębalski M., 2001, Miejski system infrastruktury społecznej, [w:] Brol R. (red.), Ekonomika zarzadzania miastem, Wrocław.

Palonka K.M., 1992, Stan i zróżnicowanie przestrzenne infrastruktury społecznej na wsi, Polska Akademia Nauk - Instytut Rozwoju Wsi i Rolnictwa, 5, Warszawa.

Podoski K., 1978, Infrastruktura społeczna w Polsce. Stan i perspektywy, PWE, Warszawa.

Rajchel D., 2004, Infrastruktura społeczna czynnikiem rozwoju obszarów podmiejskich na przykładzie powiatu opolskiego, [w:] Słodczyk J., Rajchel D. (red.), Przemiany demograficzne i jakość życia ludności miast, Uniwersytet Opolski, Opole: 253-269. 
Rogoziński K., 1993, Ustugi rynkowe, Akademia Ekonomiczna w Poznaniu, Poznań.

Rutkowska G., 2007, Analiza porównawcza infrastruktury technicznej i społecznej $w$ wybranej gminie z wymogami UE, Przegląd Naukowy - Inżynieria i Kształtowanie Środowiska, 16, Warszawa.

Sadowy M., 1988, Infrastruktura komunalna jako czynnik rozwoju miast polskich, Szkoła Główna Planowania i Statystyki w Warszawie, Warszawa.

Strategia Rozwoju Gminy Stryków na lata 2014-2020, 2013, UMiG, Stryków.

Studium uwarunkowań i kierunków zagospodarowania przestrzennego gminy Stryków, 2008, UMiG, Stryków.

Wielka encyklopedia PWN (red. J. Wojnowski), 2002, t. 25, Wydawnictwo Naukowe PWN, Warszawa.

Witkowski K., Starościc D., 2008, System infrastruktury społecznej w gminie, „Studia Lubuskie", 4, PWSZ IPiA, Sulechów.

\section{Źródła internetowe}

http://geoportal.lodzkie.pl (dostęp: 28.02.2017).

http://land.copernicus.eu/pan-european/corine-land-cover/view (dostęp: 15.10.2017).

http://stat.gov.pl/ (dostęp: 28.02.2017).

http://www.codgik.gov.pl (dostęp: 15.10.2017).

Historia artykutu

Data wpływu: 29 września 2017

Data akceptacji: 5 listopada 2017 